\title{
Growth, mortality and susceptibility of oyster Crassostrea spp. to Perkinsus spp. infection during on growing in northeast Brazil
}

\author{
Crescimento, mortalidade e susceptibilidade de ostras Crassostrea spp. à infecção \\ por Perkinsus spp. em cultivo no Nordeste do Brasil
}

Marcos Paiva Scardua ${ }^{1,2}$; Rogério Tubino Vianna ${ }^{3,4}$; Sâmia Sousa Duarte ${ }^{5}$; Natanael Dantas Farias ${ }^{5}$; Maria Luíza Dias Correia ${ }^{5}$; Helen Taynara Araújo dos Santos ${ }^{3}$; Patricia Mirella da Silva ${ }^{3,5 *}$

\author{
${ }^{1}$ Embrapa Tabuleiros Costeiros, Aracajú, SE, Brasil \\ ${ }^{2}$ Instituto Federal de Educação Ciência e Tecnologia do Ceará - IFCE, Aracati, CE, Brasil \\ ${ }^{3}$ Núcleo de Engenharia de Pesca, Universidade Federal de Sergipe - UFS, Aracajú, SE, Brasil \\ ${ }^{4}$ Universidade Federal do Rio Grande - FURG, Rio Grande, RS, Brasil \\ ${ }^{5}$ Laboratório de Imunologia e Patologia de Invertebrados, Departamento de Biologia Molecular, Centro de Ciências Exatas e da \\ Natureza, Universidade Federal da Paraíba - UFPB, João Pessoa, PB, Brasil
}

Received May 18, 2017

Accepted October 4, 2017

\begin{abstract}
Crassostrea rhizophorae and C. gasar oysters are cultivated in the northeast region. Perkinsus parasites infect bivalves, and their effects on oysters from tropical regions are poorly understood. This study evaluated the impact of Perkinsus infection on the productive traits of native oysters. Oysters were sampled bimonthly during 7 months, from July 2010 to February 2011, to evaluate growth rate, mortality and shell color patterns (white and dark-gray) $(\mathrm{n}=500)$, and to determine the prevalence and intensity of Perkinsus $(\mathrm{n}=152)$. Perkinsus and Crassostrea species were determined using molecular tools. Results showed that most dark-gray $(90 \%, \mathrm{n}=20)$ and white $(67 \%, \mathrm{n}=18)$ oysters were $C$. gasar and C. rhizophorae, respectively. Oysters showed a high growth rate and moderate cumulative mortality (44\%). C. gasar oysters grew better and showed lower mortality and lower incidence of Perkinsus compared to C. rhizophorae. The mean prevalence of Perkinsus was moderate (48\%), but the infection intensity was light (2.2). Perkinsosis affected very small oysters $(19.4 \mathrm{~mm})$. In conclusion, native oysters, especially C. gasar, have a great potential for culture, mortality is not associated with perkinsosis, and the shell color of oysters can be used to improve selection for spats with better performance.

Keywords: Oyster productive traits, Perkinsus marinus, Perkinsus beihaiensis, PCR-RFLP, ITS rDNA, 16S mtDNA.

\section{Resumo}

Crassostrea rhizophorae e C. gasar são cultivadas na região Nordeste. Parasitas Perkinsus infectam bivalves e seus efeitos em ostras de regióes tropicais são pouco compreendidos. Este estudo avaliou o impacto da infecção por Perkinsus em parâmetros de produçáo de ostras nativas. Ostras foram coletadas bimestralmente durante 7 meses, de julho de 2010 a fevereiro de 2011, para avaliar crescimento, mortalidade e padrão de coloração da concha (branca e cinza-escura) ( $\mathrm{n}=500)$; além da presença e intensidade de Perkinsus $(\mathrm{n}=152)$. Perkinsus e Crassostrea foram identificados por abordagem molecular. Os resultados mostraram que as ostras cinza-escuras $(90 \%, \mathrm{n}=20)$ e brancas $(67 \%, \mathrm{n}=18)$ eram $C$. gasar e C. rhizophorae, respectivamente. As ostras mostraram uma boa taxa de crescimento e mortalidade acumulada moderada (44\%). C. gasar cresceu melhor com menor mortalidade e menor incidência de Perkinsus que C. rhizophorae. A prevalência média de Perkinsus foi moderada (48\%), mas a intensidade de infecção foi leve (2,2). A perkinsiose afetou ostras pequenas (19,4 mm). Em conclusão, ostras nativas, especialmente $C$. gasar, têm grande potencial de produção; sem mortalidade associada à perkinsiose; e, a cor da concha pode ser usada para melhorar a seleção de sementes com melhor desempenho.

Palavras-chave: Parâmetros de produção de ostras, Perkinsus marinus, Perkinsus beihaiensis, PCR-RFLP, ITS rDNA, $16 S$ mtDNA.
\end{abstract}

\footnotetext{
*Corresponding author: Patricia Mirella da Silva. Departamento de Biologia

Molecular, Centro de Ciências Exatas e da Natureza, Universidade Federal

da Paraíba - UFPB, Jardim Universitário, s/n, Bairro Castelo Branco,

CEP 58051-900, João Pessoa, PB, Brasil. e-mail: mirella_dasilva@hotmail.com
} 


\section{Introduction}

Two mangrove oyster species, Crassostrea rhizophorae and C. gasar, inhabit the estuaries of the northeast region of Brazil. Additionally, they have wide geographical distribution, with $C$. rhizophorae inhabiting from the southern Caribbean to Uruguay and C. gasar from South America to Africa (LAPĖGUE et al., 2002).

Mangrove oysters are produced in the northeast region of Brazil using artisanal techniques, which include the sampling of naturally settled spats at different places in an estuary (bottom substrate, roots of mangrove tree, and culture structures) and hand-managing oysters for all culture stages. Estimates of the oyster production in northeastern Brazil are scarce and underestimated. In contrast, the state of Santa Catarina (SC, South Brazil) is the biggest national producer of bivalves (17,000 tons of Perna perna mussels and 3,000 tons of $C$. gigas) (SANTOS \& COSTA, 2015). The production of the exotic Japanese oyster $C$. gigas (POLI, 2004) depends on hatchery-reared spats and has a somewhat mechanized system. Since 1990, spats are annually produced by the Laboratory of Marine Mollusks at the Federal University of Santa Catarina and are sold to local farmers. In contrast, recently (2014), a private enterprise implemented a hatchery facility in the northeast region to produce spats of $C$. gasar (DA SILVA et al., 2016). However, the supply of continuous spats is not certain because of the high costs of running these facilities and the need for financial support.

Genetic variability among native mangrove oyster populations is high (LAZOSKI et al., 2011), which is reflected by the wide variation in shell morphology and shell color. Additionally, due to their phenotypic plasticity, distinguishing between the two sympatric oyster species by morphological characteristics becomes very difficult. Therefore, Rios (2009) considered mangrove oysters from Brazil to be the same species (C. rhizophorae). By contrast, Absher (1989) observed some differences in growth rates and larval morphology among sympatric lineages of Crassostrea, which supports the existence of two species, C. rhizophorae and C. gasar. Notwithstanding, observations by oyster farmers indicate two macroscopically distinguishable shell color patterns, white and dark-gray. They noticed potentially different performances of these oysters in culture as well. White oysters seemed to take a longer time to reach commercial size (pers. comm.). Since the shell color patterns of these oysters could represent different oyster species, choosing the correct species for production is desirable, especially considering the lack of hatchery-reared spats. Nevertheless, the performances of these two oyster species in culture have never been directly compared.

In Brazil, C. gigas production is already consolidated, while native oyster production is still in the exploratory phase. Recently, some studies were conducted in order to evaluate oyster maturation (RAMOS et al., 2014), larval settlement (SILVEIRA et al., 2011) and performance in culture (LOPES et al., 2013).

Perkinsosis is a disease caused by protozoan parasites from the Perkinsus genus, which includes two species, Perkinsus marinus and $P$. olseni, which are responsible for mortality in their hosts, consisting of $C$. virginica and Ruditapes spp. (VILLALBA et al., 2011). Perkinsus spp. were recently reported in Brazil, infecting
C. rhizophorae and C. gasar oysters and Anomalocardia brasiliana clams from the northeastern region (DA SILVA et al., 2013; FERREIRA et al., 2015; LUZ \& BOEHS, 2016; QUEIROGA et al., 2013, 2015; SABRY et al., 2009, 2013). P. marinus and P. olseni are both notifiable to the World Organisation for Animal Health (OIE) and were reported to infect C. gasar oysters from the estuary of the São Francisco River, Sergipe State (DA SILVA et al., 2014).

Little is known about the dynamics of Perkinsus spp. infection in tropical bivalve species under cultured conditions (DA SILVA et al., 2014, 2016; LUZ \& BOEHS, 2016). No differences in P. beihaiensis prevalence was observed among cultured (61\%) and wild (77\%) C. rhizophorae oysters from Bahia state (LUZ \& BOEHS, 2016), while prevalence varied in oysters (cultured $80 \%$ and wild 57\%) from the Sergipe state, probably because in the latter region, there are two species of Perkinsus and Crassostrea oysters (DA SILVA et al., 2014).

For the oyster industry, it is imperative to know the impact of Perkinsus spp. on the productive traits of oysters, such as growth and mortality, during the complete cultured period. For the first time, Da Silva et al. (2016) evaluated the incidence of Perkinsus sp. in $C$. gasar oysters from spats reared in a hatchery facility to adult (commercial size) during growth in shrimp ponds. Mortality was not estimated. However, the effects of Perkinsus spp. on oysters cultured in Brazilian estuaries and marine environments were never analyzed.

The aim of the present study was to investigate oyster growth and mortality, identify the oyster species according to the shell color patterns and assess the impact of Perkinsus spp. on oysters during the entire outgrowth period.

\section{Materials and Methods}

\section{Experimental design for oyster on growing}

Oysters were cultured in a suspended - fixed system in the estuary of the River São Francisco (10³2’ 0.60” S, 36²9’36.24” W) in the Sergipe state of northeastern Brazil (Figure 1).

In July 2010 , spats $(\mathrm{n}=1,000)$ were obtained from a natural settlement on culture structures (ropes, bags, and stakes) and distributed into two nurseries bags $\left(1 \mathrm{~m}^{2}\right)$ with 500 oysters on each. Oyster spats ( $n=50$ per bag) were sampled for their initial biometry (shell height and whole weight), determination of their shell color (white or dark-gray) and Perkinsus spp. diagnosis by PCR ( $\mathrm{n}=12$; Table 1).

Oysters were sampled bimonthly (September, October, and December 2010 and February 2011) in duplicates $(n=50)$ or quadruplicates $(\mathrm{n}=25)$, totalizing 100 oysters per month to estimate the shell height, whole weight as well as the oyster shell color. For Perkinsus spp. diagnosis by Ray's fluid thioglycollate medium (RFTM) oysters were sampled in duplicates $(n=15)$ or quadruplicates $(n=10)$, totalizing 30 or 40 oysters per month.

The mortality rate was estimated as the proportion of dead oysters at each bimonthly sample, in duplicates $(\mathrm{n}=50)$ or quadruplicates $(n=25)$, totalizing 100 oysters per month and the cumulative mortality was the sum of the mortality rates. The shell color of dead oysters was also recorded. 


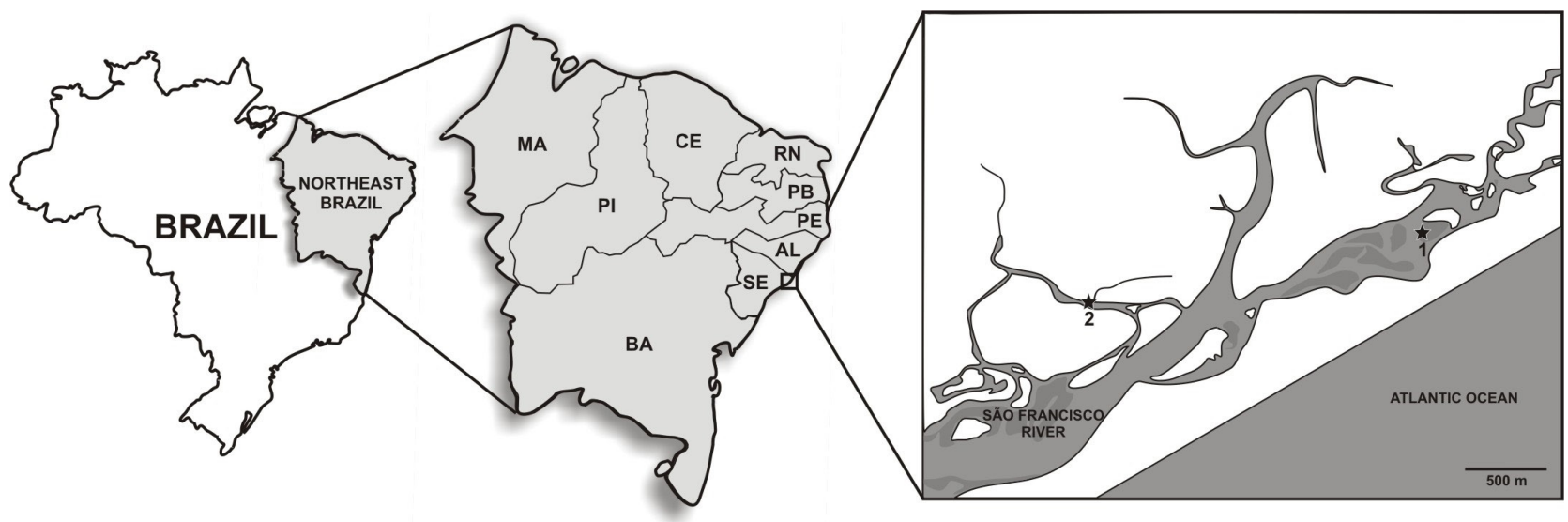

Figure 1. Map of Brazil showing the Northeastern region, the estuary of the São Francisco River and the sampling site $(* 1)$ where oysters were cultivated.

Table 1. Number of oysters used for Perkinsus diagnosis and the identification of parasite and host species. Sequenced samples were the same used for PCR-RFLP.

\begin{tabular}{lcc}
\hline \multicolumn{1}{c}{ Diagnosis } & Perkinsus & Crassostrea \\
\hline RFTM & 138 & - \\
PCR & 12 & - \\
PCR-RFLP & 25 & 38 \\
Sequencing & 12 & 12 \\
\hline
\end{tabular}

RFTM - Ray's fluid thioglycollate medium

\section{Perkinsus spp. diagnosis}

Gills were excised from each oyster and divided into two fragments, which were (i) incubated in RFTM (RAY, 1966) and (ii) preserved in $96 \%$ ethanol for molecular diagnosis. After 7 days of incubation in RFTM at room temperature in darkness, the gills were chopped, stained with lugol and analyzed for the presence and intensity of Perkinsus hypnospores. Oysters were classified using the Mackin (1962) intensity scale adapted by Da Silva et al. (2013), including uninfected (level 0 ) or infected oysters (1- very lightly, 2- lightly, 3- moderately and 4-heavily).

The mean of the infection was estimated as the sum of the infection intensity levels (1-4) divided by the number of infected oysters at each sampling time (BUSH et al., 1997). The prevalence of Perkinsus sp. infections was estimated as the proportion of infected oysters at each sampling time.

\section{PCR assays}

The oyster gill samples $(50-80 \mathrm{mg}$ ) were submitted for DNA extraction with a DNAzol (Invitrogen, Brazil) reagent, according to the manufacturer's instructions (Table 1).

To identify the species of Perkinsus, the ITS regions of the Perkinsus spp. gene complexes were amplified from the isolated DNAs using the genus-specific primers PerkITS-85 and PerkITS-750 (CASAS et al., 2002). These primer pairs were used to amplify a specific region of the internal transcriber spacer (ITS) of the small subunit of ribosomal RNA (SSU rRNA) in the genomic DNA. DNA samples from in vitro cell cultures of $P$. olseni, from $P$. marinus-infected oysters (GenBank JX144335) (DA SILVA et al., 2013) and from P. beihaiensis-infected oysters (GenBank FJ472346) (SABRY et al., 2009) were used as controls for the PCR and PCR-RFLP analyses.

To identify the species of Crassostrea, PCR reactions were performed as previously described (DA SILVA et al., 2013). The primer pairs (16SAR - 16SBR) were used to amplify a region of the mitochondrial DNA of the large subunit of ribosomal RNA (16S). DNA samples of C. gasar, C. rhizophorae and C. gigas oysters were used as controls for the PCR and PCR-RFLP analyses.

For both PCRs, the reactions were done in a total volume of $25 \mu \mathrm{l}$, containing $1 \mu \mathrm{l}$ of genomic DNA (50 ng), buffer at $1 \mathrm{x}$ concentration, $\mathrm{MgCl} 2$ at $1.5 \mathrm{mM}, 0.2 \mathrm{mM}$ nucleotides, $0.4 \mu \mathrm{M}$ of primers, and $0.04 \mathrm{U} / \mu \mathrm{l}$ of Taq DNA polymerase (Invitrogen, Brazil). PCR products were electrophoresed on $1.5 \%$ agarose gels, stained with ethidium bromide, and visualized by UV illumination.

\section{Restriction Fragment Length Polymorphism (RFLP) analysis}

The freshly amplified ITS region of Perkinsus rDNA from DNA samples of 25 Perkinsus-infected oysters (Table 1) and control DNA samples (P. olseni, P. marinus, P. beihaiensis) were digested with the enzyme Hinfl (ABOLLO et al., 2006; QUEIROGA et al., 2015) following the manufacturer's protocols (Fermentas, Brazil). Similarly, PCR-RFLP analysis was performed to identify oyster species among 25 Perkinsus sp.-infected oysters and 13 uninfected individuals from all sampling dates and color patterns, including white (18) and dark-gray (20) (Table 1). The freshly amplified 16S mtDNA products were digested with the enzyme AluI (Fermentas, Brazil) (DA SILVA et al., 2013). Restriction patterns were compared with those obtained from the control species (Perkinsus spp. and Crassostrea spp.). Ten microliters of digestion products were resolved on an $8 \%$ polyacrylamide gel and then stained with ethidium bromide.

\section{DNA sequencing and phylogenetic analyses}

The freshly amplified ITS region of Perkinsus rDNA and Crassostrea 16S mtDNA from 12 DNA samples each (Table 1) were sequenced by ACTGene Análises Moleculares Ltda. 
(Centro de Biotecnologia, UFRGS, Porto Alegre, RS, Brazil) using the automatic sequencer ABI-PRISM 3100 Genetic Analyzer (Applied Biosystems). Samples were prepared following the protocol recommended by the manufacturer.

Sequences of rDNA-ITS of Perkinsus and 16S mtDNA of Crassostrea were aligned using ClustalW (THOMPSON et al., 1994) in BioEdit 5.0.9 (HALL, 1999). Parsimony bootstrap analyses were done with MEGA 7.0 (KUMAR et al., 2016) with 100 random additions of 1,000 replicates. Bootstrap support values above 50\% (Perkinsus) and 70\% (Crassostrea) were calculated. The ITS tree was rooted with the P. qugwadi ITS-region sequence (GenBank no. AF151528), and the 16S mtDNA tree was rooted with Saccostrea glomerata (GenBank no. AF458911) and Ostrea edulis (GenBank no. JF808187). The nucleotide sequences reported in this paper are available in GenBank under the accession numbers MF595808 - MF595812 (P. beihaiensis); MF595813 - MF595819 (P. marinus); MF663010 - MF663016 (C. gasar); MF663017 - MF663018 (C. gigas) and MF663019 - MF663025 (C. rhizophorae).

\section{Results}

\section{Oyster growth and mortality}

The oysters were cultivated for 7 months. The initial mean length and weight of the spats were $28.7 \pm 1.06 \mathrm{~mm}$ and $4.1 \pm 0.44 \mathrm{~g}$, respectively. Oysters grew from July to October; although they continued to grow in length, their weight decreased from October $(73.8 \pm 4.92 \mathrm{~g})$ to December $(34.8 \pm 1.55 \mathrm{~g})$. At the end of the growing period, the oysters reached a mean length of $69.0 \pm 1.07 \mathrm{~mm}$ and weight of $50.0 \pm 1.68 \mathrm{~g}$ (Figure 2 ). This growth corresponded to an average monthly growth of $5.8 \mathrm{~mm}$ and $6.6 \mathrm{~g}$. Regarding the oysters with different color patterns, the dark-gray oysters grew significantly $(P<0.05)$ larger $(70.0 \pm 1.17 \mathrm{~mm}$ and $51.9 \pm 1.76 \mathrm{~g})$ than the white oysters $(64.2 \pm 2.30 \mathrm{~mm}$ and $43.1 \pm 4.16 \mathrm{~g})$.

The highest monthly mortality rate was in September, two months following deployment. The cumulative mortality at the end of the study was $43.6 \%$. The white oysters showed a higher cumulative mortality $(52.4 \%)$ than the dark-gray oysters $(34.8 \%)$ (Figure 3).

\section{Incidence of Perkinsus spp. during on growing}

The mean prevalence of Perkinsus spp. was moderate (47.8\%) during the growing period, except in October when it increased to $72.4 \%$ (Figure 4). The mean intensity of the Perkinsus sp. was 2.2, which corresponded to a light intensity over a 4-point scale. The prevalence of Perkinsus spp. infecting oysters (spats), in July, which was estimated by PCR, was 50\% (Figure 4). The smallest infected oyster was $19.4 \mathrm{~mm}$.

The incidence of Perkinsus spp. in oysters according to shell color was determined. The white oysters were more affected by perkinsosis (19 from 34, 55.9\%) than dark-gray oysters (50 from $116,43.1 \%)$.

\section{Identification of Crassostrea oysters by PCR-RFLP}

Thirty-eight oysters with distinct shell color patterns (18 white and 20 dark-gray) were collected throughout the study period and analyzed by PCR-RFLP in order to identify the oyster species (Table 1).

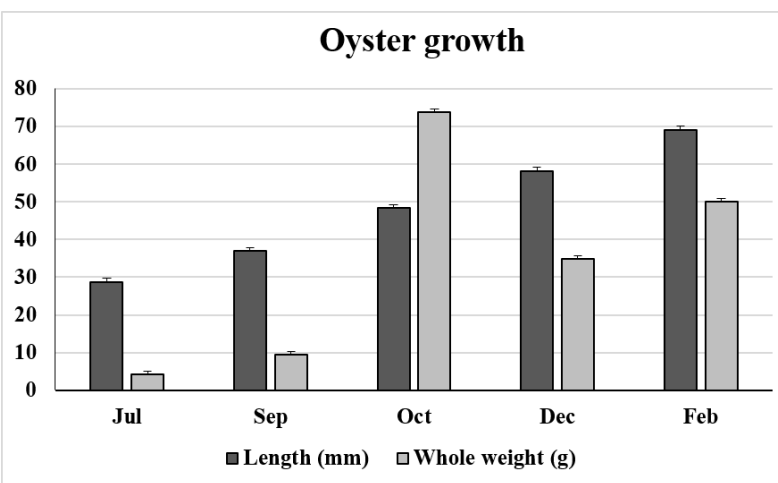

Figure 2. Mean length ( $\mathrm{mm}$ ) and whole weight (g) of oysters. Oysters were sampled in duplicates $(n=50)$ or quadruplicates $(n=25)$, totalizing 100 oysters per month.

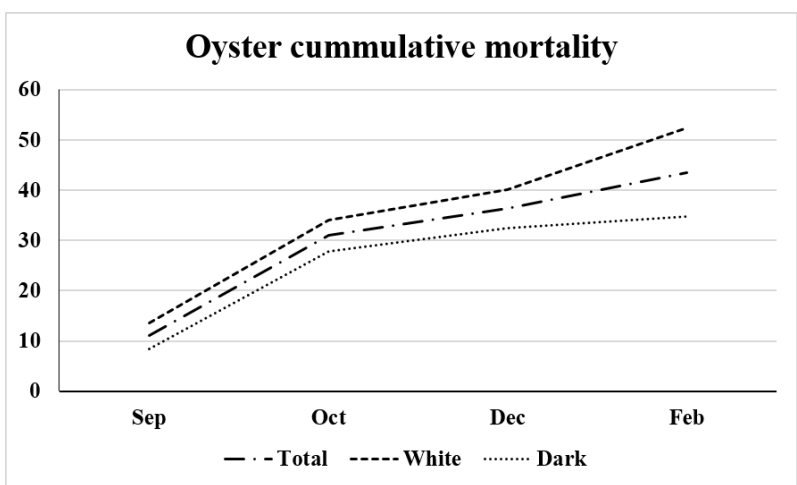

Figure 3. Total cumulative mortality of the oysters (\%) and by oyster shell color (white and dark-gray). Mortality was estimated in duplicates $(n=50)$ or quadruplicates $(n=25)$, totalizing 100 oysters per month.

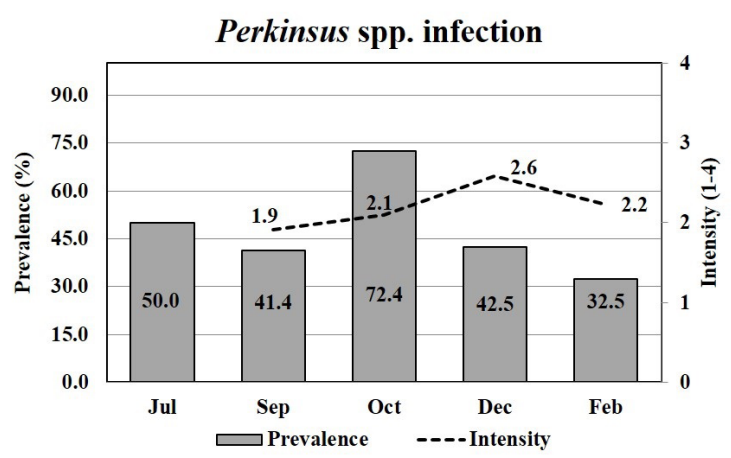

Figure 4. The prevalence of Perkinsus spp. (bar) and mean infection intensities (line) in Crassostrea spp. oysters through oyster growth. Oysters were analyzed by RFTM in duplicates (15) or quadruplicates (10), totalizing 30 or 40 oysters per month; except in July, when oysters $(\mathrm{n}=12)$ were analyzed by PCRs. 
Two distinct fragmentation patterns of the $16 \mathrm{~S}$ mtDNA using the endonuclease $A l u \mathrm{I}$ were obtained (Table 2). In 24 oysters, the digestion produced one large fragment of $\sim 250 \mathrm{bp}$ and a group of unresolved fragments smaller than $100 \mathrm{bp}$, corresponding to C. gasar. Of these, 18 were dark-gray oysters (90\%) (Table 2). In 14 oysters, the restrictive pattern showed one large fragment with slightly more than $400 \mathrm{bp}$ and a group of unresolved fragments of less than $100 \mathrm{bp}$, corresponding to C. rhizophorae. Of these, 12 were white oysters $(66.7 \%)$ (Table 2$)$.

\section{Susceptibility of Crassostrea spp. to Perkinsus spp.}

Twenty-five oysters collected throughout the study period were analyzed by PCR-RFLP in order to identify the parasite and the host species in the same sample (Table 1).

Two distinct rDNA ITS fragmentation patterns were obtained with Hinfl, which corresponded to $P$. marinus and $P$. beihaiensis (Table 3). Eleven samples showed the $P$. marinus pattern, which was four fragments of approximately 365, 150, 98 and 56 bp. Seven samples showed the $P$. beihaiensis pattern, which was a group of four fragments with the sizes ranging from 100 to $200 \mathrm{bp}$ (quadruplet) and one smaller than $\sim 10 \mathrm{bp}$. Seven oysters shared both patterns, indicating dual-infection (Table 3). P. marinus infected more $C$. rhizophorae, while $P$. beihaiensis infected more C. gasar oysters (Table 3).

The intensity of infection according to the Perkinsus spp. was also determined. The results indicated that $P$. marinus seems to

Table 2. Identification of oyster species by PCR-RFLP in relation to shell color patterns.

\begin{tabular}{cccc}
\hline \multirow{2}{*}{ Shell color pattern } & \multicolumn{2}{c}{ Oyster species } & \multirow{2}{*}{ N } \\
\cline { 2 - 3 } & C.rhizophorae & C. gasar & \\
\hline White & $\mathbf{1 2}(\mathbf{6 6 . 7} \%)$ & $6(33.3 \%)$ & $\mathbf{1 8}$ \\
Dark-gray & $2(10 \%)$ & $\mathbf{1 8}(\mathbf{9 0} \%)$ & $\mathbf{2 0}$ \\
Total & $\mathbf{1 4}$ & $\mathbf{2 4}$ & $\mathbf{3 8}$ \\
\hline
\end{tabular}

Table 3. Identification of parasite species by PCR-RFLP in relation to the oyster species. Percentages were calculated considering the rows (Perkinsus spp.) or (/) columns (Crassostrea spp.).

\begin{tabular}{cccc}
\hline \multirow{2}{*}{ Perkinsus spp. } & \multicolumn{2}{c}{ Oyster species } & \multirow{2}{*}{ N } \\
\cline { 2 - 3 } & C. rhizophorae & C. gasar & \\
\hline P. marinus & $7(\mathbf{6 4 / 5 8} \%)$ & $4(36 / 31 \%)$ & $\mathbf{1 1}$ \\
P. beihaiensis & $2(29 / 17 \%)$ & $\mathbf{5 ( 7 1 / 3 8 \% )}$ & 7 \\
Dual infection & $3(43 / 25 \%)$ & $4(57 / 31 \%)$ & 7 \\
Total & $\mathbf{1 2}$ & $\mathbf{1 3}$ & $\mathbf{2 5}$ \\
\hline
\end{tabular}

Table 4. Identification of parasite species by PCR-RFLP in relation with the parasite burden on the host.

\begin{tabular}{ccclcc}
\hline \multirow{2}{*}{ Perkinsus spp. } & \multicolumn{4}{c}{ Intensity of Perkinsus spp. infection } & \multirow{2}{*}{ N } \\
\cline { 2 - 5 } & Very light & Light & Moderate & Heavy & \\
\hline P. marinus & $2(22 \%)$ & 0 & $2(22 \%)$ & $\mathbf{5 ( 5 6 \% )}$ & $\mathbf{9}$ \\
P. beihaiensis & $2(28.7 \%)$ & $2(28.7 \%)$ & $2(28.7 \%)$ & $\mathbf{1}(\mathbf{1 3 . 9} \%)$ & 7 \\
Dual-infection & 0 & $2(67 \%)$ & 0 & $1(33 \%)$ & $\mathbf{3}$ \\
Total & & & & & $\mathbf{1 9}$ \\
\hline
\end{tabular}

have a greater capacity to proliferate and reach heavier infection intensities (56\%) in the host than P. beihaiensis (13.9\%) (Table 4).

The smallest white and dark-gray infected oysters had shell heights of $19.4 \mathrm{~mm}$ and $25.6 \mathrm{~mm}$, respectively.

\section{Phylogenetic analysis}

The results of the $16 \mathrm{~S}$ mtDNA phylogenetic analyses of the 12 Crassostrea spp. and the ITS sequences of the 12 Perkinsus spp. obtained during this study were $100 \%$ coincident with the species identifications from the PCR-RFLP analyses, since the sequences were grouped into monophyletic clades. C. rhizophorae and C. gasar had bootstrap support values of $96 \%$ and $99 \%$, respectively (Figure 5) and P. marinus and P. beihaiensis had bootstrap support values of $99 \%$ and $90 \%$, respectively (Figure 6).

\section{Discussion}

The present study evaluated, for the first time, the impact of perkinsosis on the productive traits of Crassostrea spp. oysters cultured in Brazil as well as the susceptibility of two native oyster species, C. rhizophorae and C. gasar to P. beihaiensis and P. marinus infection.

Comparison of the productive traits among the native oyster population cultivated in Brazil is a challenge because of the wide differences in experimental conditions employed, including the spats origins (mangrove or hatchery), starting spats size, time of culture, culture methods, and geographical location. Oysters from the present study showed a similar growth rate $(5.8 \mathrm{~mm}$ and $6.6 \mathrm{~g}$ per month) compared to C. gasar oysters grown in shrimp ponds in the neighboring state of Rio Grande do Norte $(5.2 \mathrm{~mm}$ per month) (DA SILVA et al., 2016). Moreover, the growth rate was better than oysters growing in shrimp ponds in the Sergipe state (2.37 mm per month) (ROSA, 2014) as well as in the marine and estuarine environments of South Brazil using spats produced in a hatchery facility (LOPES et al., 2013; PEREIRA et al., 2001). The latter authors reported oyster growth rates of $2.6 \mathrm{~mm}, 3.1 \mathrm{~mm}$ and $3.9 \mathrm{~g}$ per month.

A decrease of the mean whole weight observed in December and February compared with October could be related to spawning events, which caused an important decrease in body weight, as already described in C. rhizophorae from Brazil (NASCIMENTO \& PEREIRA, 1980; REBELO et al., 2005). Cultured C. gasar oysters became mature and present several spawning peaks during most parts of the year (PAIXÁO et al., 2013; RAMOS et al., 2014). It is important to consider that the oyster growth data presented here represents the mean of two different oyster species, which were likely pulled down by the species with the worst performance. Indeed, white oysters grew worse than dark-gray oysters.

The mean cumulative mortality observed was moderately high (43.6\%) for native Crassostrea spp. oysters produced in Brazil. Studies developed in the south of Brazil (Santa Catarina State) showed low mortality rates $(7.5 \%)$ when using culture hatchery-reared Crassostrea spp. spats (MACCACCHERO et al., 2007) and cumulative mortalities ranged from 10 to $36 \%$ when using $50 \mathrm{~mm}$ mangrove-obtained spats (PEREIRA et al., 2001). 


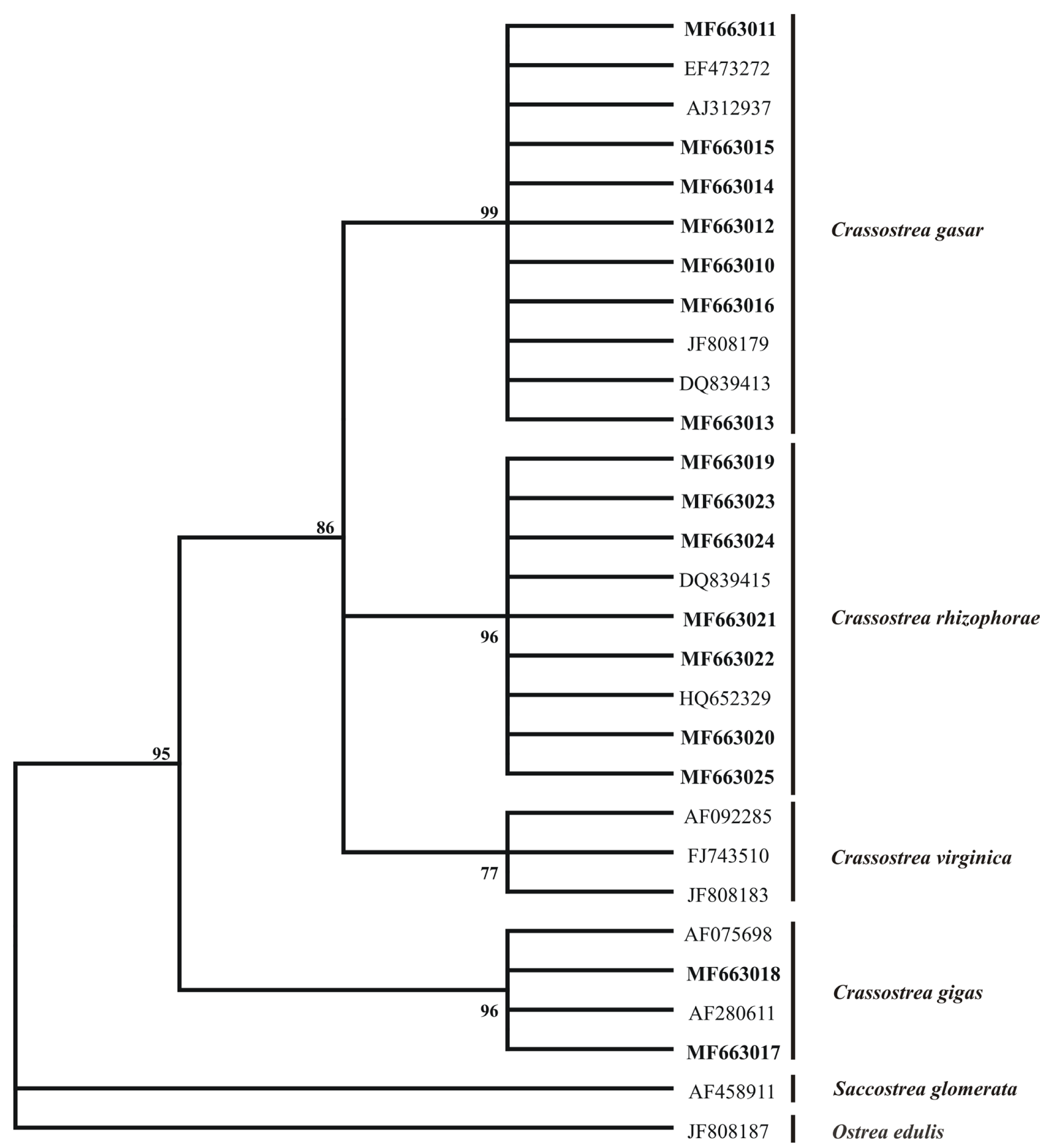

Figure 5. Phylogram showing the results of the maximum parsimony analyses on Crassostrea spp. 16S mtDNA sequences. Bootstrap support values are indicated at the nodes. Sequences from this study are indicated by GenBank accession number (in bold). Sequences MF663016 (C. gasar), MF663025 (C. rhizophorae) and MF663017 - MF663018 (C. gigas from Santa Catarina State) were the controls used for PCR-RFLP.

Notably, in the present study, white oysters showed higher cumulative mortality (52.4\%) than dark-gray oysters $(34.8 \%)$ under the same culture conditions.

The restriction patterns and the analyzed $165 \mathrm{mtDNA}$ sequences indicated that most white oysters belong to $C$. rhizophorae species and dark-gray oysters belong to C. gasar species. Therefore, C. gasar showed better performance in culture than $C$. rhizophorae, reaching larger sizes and showing higher survival. These results corroborate the assumption of producers and suggest that $C$. rhizophorae is less suitable for culture, demanding, for example, some genetic improvement.
The prevalence of Perkinsus spp. was moderate (45.7\%). Although, in October, after three months of culture, when oysters were $48.3 \mathrm{~mm}$ long, the prevalence reached the maximum value (72.4\%). This high prevalence was not associated with mortality this month (17.8\%) because the highest monthly mortality rate $(22.5 \%)$ was observed in the previous month. In addition, the light infection (level 2) in oyster tissues during the whole culture period did not support the hypothesis that Perkinsus infection caused oyster mortality. A period of high Perkinsus infection intensity commonly precedes or is concomitant with a mortality event (VILLALBA et al., 2011). 
v. 26 , n. 4 , oct. -dec. 2017

Oyster culture and Perkinsus infection

407

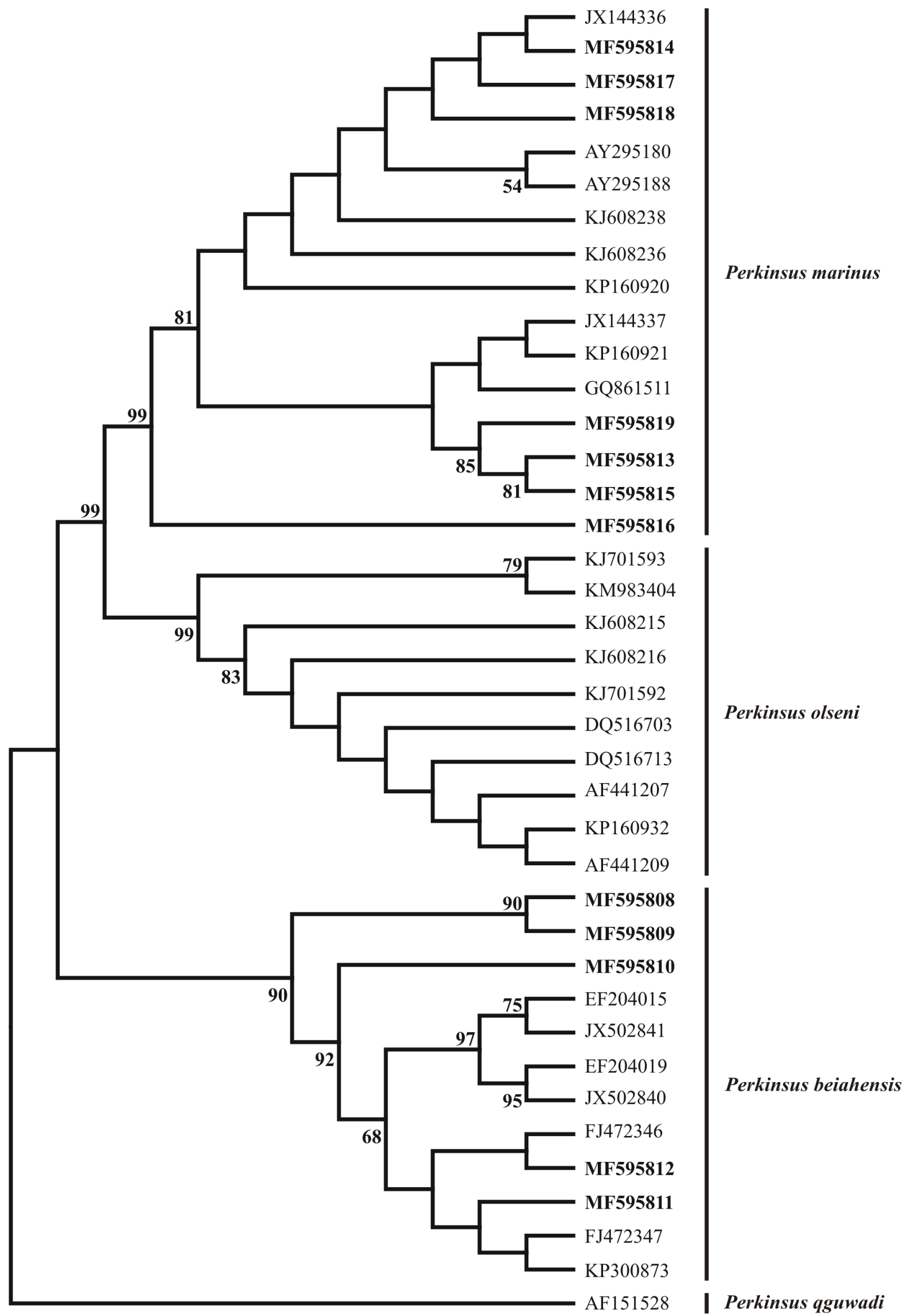

Figure 6. Phylogram showing the results of the maximum parsimony analyses on Perkinsus spp. ITS region sequences. Bootstrap support values are indicated at the nodes. Sequences from this study are indicated by GenBank accession number (in bold). 
The present study also highlights that very young oysters were already infected by Perkinsus spp. and that the infection persisted in the population until harvest. These facts suggest that the parasite is well established in the population and that it is a result of the proximity of older, infected oysters that allows parasite transmission (BEN-HORIN et al., 2015). Spats (3 - $15 \mathrm{~mm}$ ) of clams Ruditapes philippinarum also acquired infection with Perkinsus spp. (P. olseni dominant) after immersion challenge with zoospores and suffered a high mortality (SHIMOKAWA et al., 2010; WAKI et al., 2012). Concerning P. marinus, infection in C. virginica oysters smaller than $30 \mathrm{~mm}$ is rare (BURRESON, 1991). The same result was found in Crassostrea corteziensis infected by $P$. marinus of the Pacific coast of Mexico, whose prevalence was almost insignificant in oysters of $20-49 \mathrm{~mm}$ (CÁCERES-MARTÍNEZ et al., 2016). Our results are in contrast with the latter results because $50 \%$ of oysters in our study were already infected with $29 \mathrm{~mm}$ (July spats). Moreover, the present result does not support the hypothesis that larger and older oysters are more infected because of their higher filtration rate and consequently higher parasite acquisition (BURRESON \& RAGONE-CALVO, 1996; CÁCERES-MARTÍNEZ et al., 2016; VILLALBA et al., 2005).

The restriction patterns and analyzed ITS sequences identified two Perkinsus species (P. marinus and P. beihaiensis). This result allowed study of the differential susceptibility of Brazilian sympatric oysters to Perkinsus spp. infection. Interestingly, C. rhizophorae seemed to be more susceptible (55.9\%) to Perkinsus spp. infection than C. gasar (43.1\%). Herein, we put in evidence that C. rhizophorae is more affected by $P$. marinus, whose proliferation seemed to be more favored because more cases of heavy intensities were found. In turn, C. gasar is more likely to be infected by P. beihaiensis, whose proliferation seems to be more limited because fewer cases reached heavy intensities. Queiroga et al. (2015) found the opposite, that $P$. beihaiensis reached moderate and heavy intensities in $C$. gasar, while $P$. marinus seemed to be more limited. These results suggest that, when two susceptible host species are present, the progression of the two Perkinsus species can be modified in order to favor parasite progression in the most susceptible oyster species. Despite the knowledge that $P$. marinus causes outbreaks in C. virginica oysters from the East Coast of the USA (BURRESON \& RAGONE-CALVO, 1996), P. marinus was not associated with mortality in other susceptible oyster species (Crassostrea and Saccostrea) (CÁCERES-MARTÍNEZ et al., 2010, 2012, 2016; MOSS et al., 2008).

In contrast, the pathogenicity of $P$. beihaiensis is poorly studied. Moss et al. (2008) noted some histopathological effects of $P$. beihaiensis in the digestive system (stomach, intestine and digestive gland) of Crassostrea hongkongensis from China, including cases of moribund oysters with heavy infections. Similar symptoms were observed in C. rhizophorae (SABRY et al., 2009) and C. gasar (QUEIROGA et al., 2015) from Brazil. In contrast, Sanil et al. (2012) reported some digestive tubule lesions in Crassostrea madrasensis, but these lesions were not directly associated with $P$. beihaiensis.

In Brazil, a natural population of C. rhizophorae oysters (State of Paraiba, NE Brazil) is dramatically affected (prevalence up 100\% and moderate intensities, level 3) by $P$. marinus (DA SILVA et al., 2013). This oyster species is also susceptible to $P$. beihaiensis, with very low prevalence (not exceeding 10\%) and mostly light intensities (DANTAS-NETO et al., 2015; SABRY et al., 2009, 2013).

In conclusion, the occurrence of some variability in productive traits and Perkinsus spp. susceptibility between native oyster species was demonstrated. One oyster species, i.e., C. gasar, on average, showed a significantly better performance through growth. Perkinsosis did not cause mortality in any stage of oyster culture. The results obtained with the best-performing oyster species suggest that even under perkinsosis pressure and premature infection, farming in northeast Brazil is feasible and can be profitable using appropriate oyster spats and species.

\section{Acknowledgements}

This research received financial support from $\mathrm{CNPq}$ (474976/2011-4), CNPq/MPA (406170/2012-6) and CAPES (CIMAR 2202/2014). We are also grateful to the oyster producer Miguel Ferreira dos Santos.

\section{References}

Abollo E, Casas SM, Ceschia G, Villalba A. Differential diagnosis of Perkinsus species by polymerase chain reaction-restriction fragment length polymorphism assay. Mol Cell Probes 2006; 20(6): 323-329. PMid:16846717. http://dx.doi.org/10.1016/j.mcp.2006.04.001.

Absher TM. Populaçôes naturais de ostras do gênero Crassostrea do litoral do Paraná-Desenvolvimento larval, recrutamento e crescimento [thesis]. São Paulo: Universidade de São Paulo; 1989.

Ben-Horin T, Bidegain G, Huey L, Narvaez DA, Bushek D. Parasite transmission through suspension feeding. J Invertebr Pathol 2015; 131: 155-176. PMid:26210495. http://dx.doi.org/10.1016/j.jip.2015.07.006.

Burreson EM. Effects of Perkinsus marinus infection in the Eastern oyster, Crassostrea virginica: I. Susceptibility of native and MSX-resistant stocks. J Shellfish Res 1991; 10(2): 417-423.

Burreson EM, Ragone-Calvo LM. Epizootiology of Perkinsus marinus disease of oysters in Chesapeake Bay, with emphasis on data since 1985. J Shellfish Res 1996; 15(1): 17-34.

Bush AO, Lafferty KD, Lotz JM, Shostak AW. Parasitology meets ecology on its own terms: Margolis et al. revisited. J Parasitol 1997; 83(4): $575-$ 583. PMid:9267395. http://dx.doi.org/10.2307/3284227.

Cáceres-Martínez J, Madero-López LH, Padilla-Lardizábal G, VásquezYeomans R. Epizootiology of Perkinsus marinus, parasite of the pleasure oyster Crassostrea corteziensis, in the Pacific coast of Mexico. J Invertebr Pathol 2016; 139: 12-18. PMid:27403560. http://dx.doi.org/10.1016/j. jip.2016.07.003.

Cáceres-Martínez J, Ortega MG, Vásquez-Yeomans R, García TJP, Stokes NA, Carnegie RB. Natural and cultured populations of the mangrove oyster Saccostrea palmula from Sinaloa, Mexico, infected by Perkinsus marinus. J Invertebr Pathol 2012; 110(3): 321-325. PMid:22465628. http://dx.doi.org/10.1016/j.jip.2012.03.019.

Cáceres-Martínez J, Vásquez-Yeomans R, Padilla-Lardizábal G. Parasites of the pleasure oyster Crassostrea corteziensis cultured in Nayarit, Mexico. J Aquat Anim Health 2010; 22(3): 141-151. PMid:21192543. http:// dx.doi.org/10.1577/H09-052.1. 
Casas SM, La Peyre JF, Reece KS, Azevedo C, Villalba A. Continuous in vitro culture of the carpet shell clam Tapes decussatus protozoan parasite Perkinsus atlanticus. Dis Aquat Organ 2002; 52(3): 217-231. PMid:12553450. http://dx.doi.org/10.3354/dao052217.

Da Silva PM, Costa CP, Araújo JPB, Queiroga FR, Wainberg AA. Epizootiology of Perkinsus sp. in Crassostrea gasar oysters in polyculture with shrimps in northeastern Brazil. Rev Bras Parasitol Vet 2016; 25(1): 37-45. PMid:27007244. http://dx.doi.org/10.1590/S1984-29612016011.

Da Silva PM, Scardua MP, Vianna RT, Mendonça RC, Vieira CB, Dungan CF, et al. Two Perkinsus spp. infect Crassostrea gasar oysters from cultured and wild populations of the Rio Sáo Francisco estuary, Sergipe, northeastern Brazil. J Invertebr Pathol 2014; 119: 62-71. PMid:24780219. http://dx.doi.org/10.1016/j.jip.2014.04.005.

Da Silva PM, Vianna RT, Guertler C, Ferreira LP, Santana LN, FernándezBoo S, et al. First report of the protozoan parasite Perkinsus marinus in South America, infecting mangrove oysters Crassostrea rhizophorae from the Paraíba River (NE, Brazil). J Invertebr Pathol 2013; 113(1): 96-103. PMid:23439264. http://dx.doi.org/10.1016/j.jip.2013.02.002.

Dantas-Neto MP, Sabry RC, Ferreira LP, Romão LS, Maggioni R. Perkinsus sp. infecting the oyster Crassostrea rhizophorae from estuaries of the septentrional Northeast, Brazil. Braz J Biol 2015; 75(4): 10301034. PMid:26675922. http://dx.doi.org/10.1590/1519-6984.06314.

Ferreira LP, Sabry RC, Da Silva PM, Gesteira TCV, Romão LS, Paz MP, et al. First report of Perkinsus beihaiensis in wild clams Anomalocardia brasiliana (Bivalvia: Veneridae) in Brazil. Exp Parasitol 2015; 150: 67-70. PMid:25088443. http://dx.doi.org/10.1016/j.exppara.2014.07.012.

Hall T. BioEdit: a user-friendly biological sequence alignment editor and analysis program for Windows 95/98/NT. Nucleic Acids Symp Ser 1999; 41: 95-98.

Kumar S, Stecher G, Tamura K. MEGA7: molecular evolutionary genetics analysis version 7.0 for bigger dataset. Mol Biol Evol 2016; 33(7): 18701874. PMid:27004904. http://dx.doi.org/10.1093/molbev/msw054.

Lapègue S, Boutet I, Leitão A, Heurtebise S, Garcia P, Thiriot-Quiévreux $\mathrm{C}$, et al. Trans-Atlantic distribution of a mangrove oyster species revealed by $16 \mathrm{~S}$ mtDNA and karyological analyses. Biol Bull 2002; 202(3): 232242. PMid:12086994. http://dx.doi.org/10.2307/1543473.

Lazoski C, Gusmão J, Boudry P, Solé-Cava AM. Phylogeny and phylogeography of Atlantic oyster species: Evolutionary history, limited genetic connectivity and isolation by distance. Mar Ecol Prog Ser 2011; 426: 197-212. http://dx.doi.org/10.3354/meps09035.

Lopes GR, Gomes CHAM, Tureck CR, Melo CMR. Growth of Crassostrea gasar cultured in marine and estuary environments in Brazilian waters. Pesq Agropecu Bras 2013; 48(8): 975-982. http://dx.doi.org/10.1590/ S0100-204X2013000800024.

Luz MSA, Boehs G. Perkinsus beihaiensis infectando a ostra Crassostrea rhizophorae em cultivo e em estoque natural na Baía de Camamu, Bahia, Brasil. Braz J Vet Res Anim Sci 2016; 53(2): 191-198. http://dx.doi. org/10.11606/issn.1678-4456.v53i2p191-198.

Maccacchero GB, Ferreira JF, Guzenski J. Influence of stocking density and culture management on growth and mortality of the mangrove native oyster Crassostrea sp. in southern Brazil. Biotemas 2007; 20(3): 47-53.

Mackin J. Oyster disease caused by Dermocystidium marinum and other microorganisms in Louisiana. Publ Inst Mar Sci 1962; 7: 132-299.

Moss JA, Xiao J, Dungan CF, Reece KS. Description of Perkinsus beihaiensis n. sp., a new Perkinsus sp. parasite in oysters of Southern
China. J Eukaryot Microbiol 2008; 55(2): 117-130. PMid:18318865. http://dx.doi.org/10.1111/j.1550-7408.2008.00314.x.

Nascimento IA, Pereira SA. Changes in the condition index for mangrove oysters (Crassostrea rhizophorae) from Todos os Santos Bay, Salvador, Brazil. Aquaculture 1980; 20(1): 9-15. http://dx.doi.org/10.1016/00448486(80)90057-5.

Paixão L, Ferreira MA, Nunes Z, Fonseca-Sizo F, Rocha R. Effects of salinity and rainfall on the reproductive biology of the mangrove oyster (Crassostrea gasar): Implications for the collection of broodstock oysters. Aquaculture 2013; 380-383: 6-12. http://dx.doi.org/10.1016/j. aquaculture.2012.11.019.

Pereira OM, Machado IC, Henriques MB, Yamanaka N. Crescimento da ostra Crassostrea brasiliana semeada sobre tabuleiro em diferentes densidades na região estuarino-lagunar de Cananéia-SP $\left(25^{\circ} \mathrm{S}, 48^{\circ} \mathrm{W}\right)$. B Inst Pesca 2001; 27(2): 163-174.

Poli CR. Cultivo de ostras do Pacífico. In: Poli CR, Poli AT, Andreatta E, Beltrame EC. Aquicultura: experiências brasileiras. Florianópolis: Multitarefa; 2004. p. 251-266.

Queiroga FR, Marques-Santos LF, Hégaret H, Soudant P, Farias ND, Schlindwein AD, et al. Immunological responses of the mangrove oysters Crassostrea gasar naturally infected by Perkinsus sp. in the Mamanguape Estuary, Paraíba state (Northeastern, Brazil). Fish Shellfish Immunol 2013; 35(2): 319-327. PMid:23664909. http://dx.doi.org/10.1016/j. fsi.2013.04.034.

Queiroga FR, Vianna RT, Vieira CB, Farias ND, Da Silva PM. Parasites infecting the cultured oyster Crassostrea gasar (Adanson, 1757) in Northeast Brazil. Parasitology 2015; 142(6): 756-766. PMid:25553815. http:// dx.doi.org/10.1017/S0031182014001863.

Ramos CO, Gomes CHAM, Magalhães ARM, Santos AI, Melo CMR. Maturation of the mangrove oyster Crassostrea gasar at different temperatures in the laboratory. J Shellfish Res 2014; 33(1): 187-194. http://dx.doi. org/10.2983/035.033.0118.

Ray SM. A review of the culture method of detecting Dermocystidium marinum with suggested modifications and precautions. Proc Nat Shellfish Assoc 1966; 54: 55-69.

Rebelo MF, Amaral MCR, Pfeiffer WC. Oyster condition index in Crassostrea rhizophorae (Guilding, 1828) from a heavy-metal polluted coastal laggon. Braz J Biol 2005; 65(2): 345-351. PMid:16097738. http://dx.doi.org/10.1590/S1519-69842005000200019.

Rios EC. Compendium of brazilian sea shells. Rio Grande: Evangraf; 2009.

Rosa LC. Crescimento e sobrevivência da ostra Crassostrea brasiliana (Lamarck, 1819) mantida em um viveiro de cultivo de camarão. Arq Ciênc 2014; 47(1): 64-68.

Sabry RC, Gesteira TCV, Magalhães ARM, Barracco MA, Guertler C, Ferreira LP, et al. Parasitological survey of mangrove oyster, Crassostrea rhizophorae, in the Pacoti River Estuary, Ceará State, Brazil. J Invertebr Pathol2013; 112(1): 24-32. PMid:23147104. http://dx.doi.org/10.1016/j. jip.2012.10.004.

Sabry RC, Rosa RD, Magalhães ARM, Barracco MA, Gesteira TCV, Da Silva PM. First report of Perkinsus sp. infecting mangrove oysters Crassostrea rhizophorae from the Brazilian coast. Dis Aquat Organ 2009; 88(1): 13-23. PMid:20183961. http://dx.doi.org/10.3354/dao02136.

Sanil NK, Suja G, Lijo J, Vijayan KK. First report of Perkinsus beihaiensis in Crassostrea madrasensis from the Indian subcontinent. Dis Aquat Organ 2012; 98(3): 209-220. PMid:22535871. http://dx.doi.org/10.3354/ dao02440. 
Santos AA, Costa SW. Sintese informativa da maricultura. Santa Catarina: EPAGRI; 2015

Shimokawa J, Yoshinaga T, Ogawa K. Experimental evaluation of the pathogenicity of Perkinsus olseni in juvenile Manila clams Ruditapes philippinarum. J Invertebr Pathol 2010; 105(3): 347-351. PMid:20807538. http://dx.doi.org/10.1016/j.jip.2010.08.007.

Silveira RC, Silva FC, Gomes CHM, Ferreira JF, Melo CMR. Larval settlement and spat recovery rates of the oyster Crassostrea brasiliana (Lamarck, 1819) using different systems to induce metamorphosis. Braz J Biol2011; 71(2): 557-562. PMid:21755177. http://dx.doi.org/10.1590/ S1519-69842011000300029.

Thompson JD, Higgins DG, Gibson TJ. CLUSTAL W: improving the sensitivity of progressive multiple sequence alignment through sequence weighting, position-specific gap penalties and weight matrix choice.
Nucleic Acids Res 1994; 22(22): 4673-4680. PMid:7984417. http:// dx.doi.org/10.1093/nar/22.22.4673.

Villalba A, Casas SM, López C, Carballal MJ. Study of perkinsosis in the carpet shell clam Tapes decussatus in Galicia (NW Spain). II. Temporal pattern of disease dynamics and association with clam mortality. $D$ is Aquat Organ 2005; 65(3): 257-267. PMid:16119895. http://dx.doi. org/10.3354/dao065257.

Villalba A, Gestal C, Casas SM, Figueras A. Perkinsosis en moluscos. In: Figueras A, Novoa B. Enfermedades de moluscos bilvalvos de interés en acuicultura. Madrid: Fundación Observatorio Español de Acuicultura; 2011. p. 181-242.

Waki T, Shimokawa J, Watanabe S, Yoshinaga T, Ogawa K. Experimental challenges of wild Manila clams with Perkinsus species isolated from naturally infected wild Manila clams. J Invertebr Pathol 2012; 111(1): 50-55. PMid:22687350. http://dx.doi.org/10.1016/j.jip.2012.05.009. 